\title{
Article
}

\section{Psychological trauma in professionals working with traumatised children}

Ireland, Carol Ann and Huxley, Siona

Available at http://clok.uclan.ac.uk/20954/

Ireland, Carol Ann ORCID: 0000-0001-7310-2903 and Huxley, Siona (2018) Psychological trauma in professionals working with traumatised children. Journal of Forensic Practice, 20 (3). pp. 141-151. ISSN 2050-8794

It is advisable to refer to the publisher's version if you intend to cite from the work. http://dx.doi.org/10.1108/JFP-10-2017-0045

For more information about UCLan's research in this area go to http://www.uclan.ac.uk/researchgroups/ and search for < name of research Group>.

For information about Research generally at UCLan please go to http://www.uclan.ac.uk/research/

All outputs in CLoK are protected by Intellectual Property Rights law, including Copyright law. Copyright, IPR and Moral Rights for the works on this site are retained by the individual authors and/or other copyright owners. Terms and conditions for use of this material are defined in the policies page.

\section{CLoK}

Central Lancashire online Knowledge www.clok.uclan.ac.uk

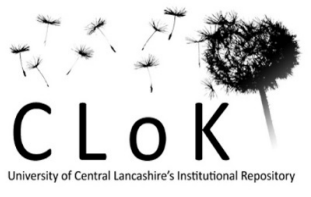




\title{
Psychological trauma in professionals working with traumatised children
}

\author{
Carol A. Ireland* \\ CCATS: Coastal Child and Adult Therapeutic Services, \\ CCATS International Research Centre, UK (www.ccats.org.uk), \\ Ashworth Research Centre, Mersey Care NHS Trust and School of Psychology, University of Central \\ Lancashire, UK
}

Siona Huxley

CCATS: Coastal Child and Adult Therapeutic Services,

CCATS International Research Centre, UK (www.ccats.org.uk)

Maastricht University, Netherlands.

*Corresponding author: caireland@uclan.ac.uk +44 (0) 1253896444

To be published in the Journal of Forensic Practice (in press) 


\section{Psychological Trauma in professionals working with traumatised children}

\section{STRUCTURED ABSTRACT:}

Purpose of this paper: Clinical professionals working with psychologically traumatised children in the care system can experience potential challenges maintaining their own positive psychological health, and when repeatedly being exposed to the traumatic histories of those in their care. The aim of this paper is to increase understanding of vicarious trauma and provide a guide for focusing future research.

Design/methodology/approach: This is a systematic literature review, considering 13 articles that met the criteria and identified five main themes linked to secondary traumatic stress/vicarious trauma in staff.

Findings: 5 main themes were noted. These are: Lack of organisational support; Lack of health work-life balance; Lack of appropriate training; Failure to use self-care techniques; and staff failure to share when they are experiencing symptoms.

Practical implications: Various implications are noted from this review. These include the importance of education and support for staff, to be mindful that newer staff may be considered an 'at risk' group for the negative impact of such trauma, and to encourage staff in achieving an effective work-life balance.

What is original/value of paper: This is a focused systematic review on secondary and vicarious trauma on staff working with children exposed to psychological trauma, such as sexual and physical abuse.

KEY WORDS: secondary traumatic stress, vicarious trauma, compassion fatigue, staff, psychological trauma, children and adolescents

To be published in the Journal of Forensic Practice (in press) 


\section{INTRODUCTION}

Vicarious trauma is considered as alterations in schemas and core beliefs resulting from exposure to the trauma of others. Secondary traumatic stress is the transfer and acquisition of negative affective and dysfunctional cognitive states occurring due to prolonged and extended contact with traumatised individuals (Mott, 2012). Some researchers define these terms as two differing concepts, yet they are increasingly being used synonymously, along with compassion fatigue (Creamer \& Liddle, 2005, McCann \& Pearlman, 1990). Compassion fatigue is defined as a state of exhaustion and dysfunction, biologically, psychologically, and socially, resulting from long and repeated exposure to compassion stress and all that it evokes (Weaks, 1999). Compassion fatigue refers to the stress felt by the professionals after exposure to traumatic material of the survivor (Weaks, 1999). Mental health workers who are exposed to highly stressful environments are considered susceptible to burnout, as well secondary traumatic stress (Wagaman et al., 2015). In a study of house support workers (Bishop \& Schmidt, 2011), it was noted that the majority of participants had heard of the term vicarious trauma, and $61 \%$ identified that their employer had discussed the impact of hearing other people's traumatic stories. However, only around a third of the participants had received specific training (Bishop \& Schmidt, 2011).

There is little research looking at vicarious or secondary trauma in residential child placements. Yet, these are environments where staff can be exposed to the developmental trauma of young people, such as sexual and physical abuse, as well as being exposed to distress from this population. As such, research from areas close to this, such as mental health workers and therapists, must then be extrapolated in order to enhance understanding. Overall, working in environments where there is psychological trauma and/or mental health issues can be stressful, as staff can in some instances be exposed to acts of violence (both physical and verbal) and other distressing events, including hearing distressing details regarding the past traumas of their clients (Kindy, Peterson \& Parkhurst, 2005; Weaks, 1999). The same challenges may then be considered when working with psychological traumatised children in the care system. Further, there is an increased prevalence of Post-Traumatic Stress Disorder (PTSD) symptoms among individuals working in a variety of environments (Skogstad et al., 2013), and where staff working with such children may be considered to theoretically fit these groups. In brief, the behavioural To be published in the Journal of Forensic Practice (in press) 
symptoms of PTSD are described as persistent re-experiencing, persistent avoidance of eventrelated stimuli, negative mood and persistent symptoms of increased arousal. These symptoms are similar to that which is experienced from vicarious or secondary trauma, although these are more likely to result when an individual listens empathically while someone shares the graphic details of their traumatic experience over an extended period of time (VanDeusen \& Way, 2006). Arguably, staff working with children in care may form part of this group, and where the young people can choose to discuss their traumatic life experiences with staff as part of dealing with their distress.

As such, any PTSD symptoms, either in part or in full, can continue to intensify if left unaddressed. This can potentially result in burnout for the professional (Brady et al., 1999; Way et al. 2004). Burnout is described as a general emotional exhaustion that professionals may develop over time as a result of various work-related stressors (Way et al. 2004). The symptoms can ultimately result in the professional no longer working with the traumatised client (Way et al. 2004), and may have further links to compassion fatigue.

\section{Personal Effects of Vicarious Trauma}

Therapists who work with traumatised clients over an extended period may begin experiencing similar symptoms to their clients. Symptoms such as intrusive thoughts, nightmares, difficulty in managing intense emotions (such as rage, shame, grief, depression and anxiety), feeling helpless and feeling vulnerable have all been reported (McElvaney \& Tatlow-Golden, 2016; Neumann \& Gamble, 1995; Osofsky, 2011; Weaks, 1999; VanDeusen \& Way, 2006). Therapists have also reported experiencing physical symptoms, such as headaches, nausea, and body aches (Motta, 2012; Neumann \& Gamble, 1995), alongside psychological symptoms, such as emotional numbing, hypervigilance and personal difficulties, such as feeling discouraged and cynical (Neumann \& Gamble, 1995; Pistorius, 2006; VanDeusen \& Way, 2006). Others report experiencing decreased self-esteem and sexual difficulties (Braley, 2010; VanDeusen \& Way, 2006), whereas some begin to feel shame as they experience the negative symptoms of vicarious trauma, losing trust in their own ability, especially in less-experienced therapists (VanDeusen \& Way, 2006). Disruptions in therapists' own schemas, such as viewing the world as less safe, have 
also been reported (Brady et al., 1999; Neumann \& Gamble, 1995; Osofsky, 2011; Pistorius, 2006; VanDeusen \& Way, 2006).

Symptoms can consequently impact on relationships, from work to personal relationships (Weaks, 1999). Lonergan et al. (2004) noted that therapists with child clients who have been sexually abused became more protective of their own children, and experienced intense fear of sexual abuse occurring in their family. However, another study noted that therapists reported appreciating life more and cherishing their children's innocence (Pistorius, 2006). Brady et al. (1999) found that when therapists listen to their client's trauma, describing the cruelty of some human behaviour, this can challenge their faith and make them question their own sense of meaning and hope (Brady et al., 1999). Damage to the therapist's spirituality is further considered to be one of the more dangerous threats to the individual's well-being (Brady et al., 1999). As such, all of these potential symptoms can apply to staff working with psychologically traumatised children.

\section{Organisational Effects of Vicarious Trauma}

If vicarious trauma goes unaddressed, it can lead to short-term and long-term emotional and physical effects, strains on relationships, substance abuse, burnout, and shortened careers (Neumann \& Gamble, 1995; Weaks, 1999). These effects can negatively impact the organisation as a whole, as staff become unable to give the quality of care needed. Burnout leads to a high staff turnover, meaning organisations continuously look for replacements and have to train new staff.

Vicarious trauma of staff can further affect the client (Weaks, 1999). For instance, if the therapist experiences feelings of helplessness and frustration, they are more likely to diagnose clients with a mental illness, particularly a personality disorder (Weaks, 1999). Further traumatisation of the client can occur if the therapist focuses on their own needs rather than those of their clients, resulting in incidents such as forgotten appointments or phone calls (Weaks, 1999). This behaviour by the therapist makes the organisation look less professional and clients may choose to consequently transfer to another therapist.

\section{Factors contributing to Vicarious Trauma}

To be published in the Journal of Forensic Practice (in press) 
While one study (Wagaman et al., 2015) noted empathy was a significant factor in aiding social workers to cope with the factors related to burnout and secondary traumatic stress, and that it contributes to the maintenance of the well-being and longevity of staff in their career, other studies found more empathetic therapists have a higher risk of developing vicarious trauma (Braley, 2010; Osofsky, 2011; Weaks, 1999). This therefore suggests that the level of empathic concern may be a factor, and that getting the balance correct is important. Further, if exposed to trauma material that was vivid, graphic, or showed that people can be intentionally cruel to each other, or the therapist shares traumatic re-enactments with clients, it can increase the likelihood of experiencing the symptoms of vicarious trauma (Weaks, 1999). These elements then affect the therapist's self-capacities, frame of reference, and safety schemas (Weaks, 1999).

Characteristics of the trauma event could further affect the likelihood of the therapist experiencing symptoms. The predictability, or unpredictability of the event, the extent to which the traumatic event violated the therapist's worldview or existing schemas, and the presence of any continued threat to the client, are all factors that could increase the individual's likelihood of developing symptoms if those factors are present (Weaks, 1999).

Organisational factors may additionally increase the likelihood of the mental health workers experiencing symptoms. Therapists with caseloads that consisted of over $50 \%$ trauma survivors were more likely to experience PTSD symptomatology than therapists that had fewer trauma survivors in their caseloads (Brady et al., 1999; Creamer \& Liddle, 2005; Osofsky, 2011; Weaks, 1999). If staff receive no supervision, there is no opportunity to discuss the challenging aspects of the cases and process the information (Weaks, 1999). Without this supervisory support, they can develop a sense of disconnection from the organisation (Weaks, 1999).

Maltreatment history (including any maltreatment, multiple treatment, physical abuse, neglect, and emotional neglect) in the therapists themselves was significantly associated with increased disruptions of schemas (VanDeusen \& Way, 2006). However, a factor in this may not be their own experiences of maltreatment per sae, but whether they have resolved any personal distress that may link to this. It is noted that emotional neglect in the clinicians was particularly associated with more disruptions in cognitions about intimacy with others (VanDeusen \& Way,

To be published in the Journal of Forensic Practice (in press) 
2006). However, contradictory results have been found, and some researchers conclude that clinicians with maltreatment history in and of itself was not significantly associated with vicarious trauma (Creamer \& Liddle, 2005; Way et al., 2004), and other factors may be if such history continues to be a stressor or not. However, a significant predictor of vicarious trauma was noted for those professionals with a history of discussing reactions to their client's traumatic material during their own therapy sessions (Creamer \& Liddle, 2005).

Less experienced staff have been observed to have an increased level of disruption in cognitions of trust and intimacy with others (Creamer \& Liddle, 2005; Neumann \& Gamble, 1995; Pistorius, 2006; VanDeusen \& Way, 2006). For example, those under significant or chronic stress were more likely to experience symptoms of vicarious trauma (Brady et al., 1999; Weaks, 1999). Weaks (1999) concluded that coping style was one of the most important factors in regard to the development of symptoms and disruptions in schemas; problem-focused coping style was linked with less PTSD symptoms and fewer disruptions in existing schemas. Using this coping style may increase the therapist's sense of trust in themselves and promote a sense of control of their own problems (Weaks, 1999). An escape-avoidance coping style was linked with significantly higher amount of cognitive disruptions in relation to their feelings of safety of self, self-control, helplessness in relationships with others, intimacy with others, and trust of others (Pistorius, 2006; Weaks, 1999). The escape-avoidance coping style was found to be used more often by individuals experiencing higher levels of symptomatology (Weaks, 1999).

\section{Personal Factors that mitigate or decrease Vicarious Trauma}

Therapists indicate a key method to mitigate or reduce the potential for vicarious trauma is to educate themselves (Brady et al., 1999; Lonergan et al., 2004; McElvaney \& Tatlow-Golden, 2016; Motta, 2012; Osofsky, 2011). Educating themselves about the field in general and, more specifically, about secondary traumatic stress, allows the mental health worker to understand that this is a common occurrence in the field, and reduces the stress of thinking they are not doing their job correctly if they are experiencing vicarious trauma (Lonergan et al., 2004). Education can also help to identify if they are experiencing any of the common symptoms and may provide helpful ways to reduce or mitigate these symptoms (Weaks, 1999). Training that 
focuses on self-awareness, emotional regulation, and affective response, both before entering the field and during their working career to mitigate secondary traumatic stress (Wagaman et al., 2015) is considered an effective approach.

Self-care techniques, such as regular exercise, eating a healthy diet, taking vacations or taking breaks from work, setting appropriate limits on work time, diversifying their caseloads, and limiting the number of particularly difficult cases are further recommended (Motta, 2012; Neumann \& Gamble, 1995; Lonergan et al., 2004; Osofsky, 2011). Decompression rituals, such as listening to calming music, spending some alone time reading, changing clothes, and exercising, can be used by the therapist to transition out of work lives into their home lives (Neumann \& Gamble, 1995). Furthermore, having a fulfilling personal life and engaging in a healthy intimate relationship can safe-guard the professional's mental health and provide additional support (Neumann \& Gamble, 1995; Osofsky, 2011). Also, becoming involved in activities that restore a sense of meaning, connection and hope are beneficial (Neumann \& Gamble, 1995). For instance, actively participating in religious services was found to predict lower burnout (Sprang et al., 2011).

\section{Organisational Factors that mitigate or decrease Vicarious Trauma}

By providing education to their employees, the organisation can ensure their staff are receiving the information they need (Brady et al., 1999; Osofsky, 2011). Braley (2010) found organisations with higher levels of education and external support for stress were associated with lower compassion fatigue scores. Arguably, organisations should take more care of newer staff and ensure that appropriate measures are in place to reduce or prevent vicarious trauma, especially since they are more likely to experience symptoms (Neumann \& Gamble, 1995).

When considering other professionals, social workers with regular support from their superiors, peers and work teams, experienced lower levels of secondary traumatic stress (Choi, 2011). Therapists reported that having supervision and dedicated time to discuss their experiences assisted them (Lonergan et al., 2004; Pistorius, 2006; VanDeusen \& Way, 2006). Offering personal therapy to their staff may give the employees an opportunity to discuss matters of their work and evaluate their own responses to their work and to certain clients (Pistorius, 
2006). It is important that the organisation displays a willingness to regularly examine systemic issues that may factor into the likelihood of staff developing symptoms (Brady et al., 1999), and they should further aim to ensure their employees have a mixed caseload that isn't too heavy with trauma clients (Pistorius, 2006). It is further recommended that employees have a suitable work-life balance (Pistorius, 2006), and the organisation should try to improve inter-agency communication, as misunderstandings between agencies can increase the level of stress on therapists (Choi, 2011; McElvaney \& Tatlow-Golden, 2016).

\section{STUDY AIMS}

Clinical professionals, including staff in residential child placements, are likely to work with young people who have survived psychological trauma during the course of their careers. Arguably, policies need to be implemented to minimise the likelihood of vicarious trauma occurring and to reduce the severity of symptoms staff may experience (Weaks, 1999). Research on vicarious trauma can help to inform such staff about ways to detect, prevent, and reduce symptoms. It can provide guidance to formulate appropriate policies. If vicarious trauma goes undetected, it can have detrimental effects on staff, their relationships with others, the organisation and negatively impact their clients (Weaks, 1999). Such considerations need to be applied to residential care staff; in the UK, there are residential homes for children who need care. The residential support workers may also be at risk of vicarious trauma, since they are often exposed to details of the past trauma of these children. There is a lack of research on the effects of this work on residential support workers, and this brief systematic review aims to address initial areas where further research is needed with this population.

\section{METHOD}

\section{Search Strategy}

Searches of PsychINFO, ERIC, E-journals, Child Development and Adolescent Studies, MEDLINE and SOCIndex databases were conducted. An initial search was conducted with the 
search terms "vicarious trauma" OR "secondary traumatic stress" combined with OR "residential workers" OR "social workers" with "Children" OR "Adolescents" OR "Youth." This initial search resulted in 3 articles that met the criteria requirements. Therefore, the search was widened, in order to include more mental health professionals. The second search included the terms "vicarious trauma" OR "secondary traumatic stress", and were combined with "mental health professionals" OR "therapists" OR "psychologists" OR "nursing staff" OR "hospitals" OR "CAMHS", and combined with "Children" OR "Adolescents" OR "Youth." There were no limits in terms of date of publication. Relevant papers were then retrieved and 45 articles were initially identified.

\section{Study selection Criteria}

The criteria for exclusion from more detailed analyses were: (1) does not mention vicarious trauma or secondary traumatic stress; (2) does not relate to working with children or adolescents; (3) does not relate to mental health professionals (seen in broad terms); (4) duplicate; (5) could not access the article. All other articles that met the previously listed requirements were then included. Of the 45 articles retrieved, 31 were excluded due to not meeting the requirements. The remaining 14 articles were read in full, and 1 article was excluded due to lack of relevance. This left a total of 13 articles for more detailed analysis. Figure 1 provides an overview of how the articles were screened and excluded, retaining the final 13 articles.

\section{Data synthesis}

Thematic synthesis (Thomas \& Harden, 2008) is a method used for qualitative data synthesis. This approach uses a similar method to analysis as grounded theory. It is based on inductive reasoning and themes are developed continuously using a comparative approach. The selected articles were read multiple times in order to ensure relevance to the study and identify the themes. The themes were discussed and agreed upon with another researcher who was not involved in the study, to ensure reliability of the themes. These themes are discussed in the results and discussion section of this paper.

To be published in the Journal of Forensic Practice (in press) 


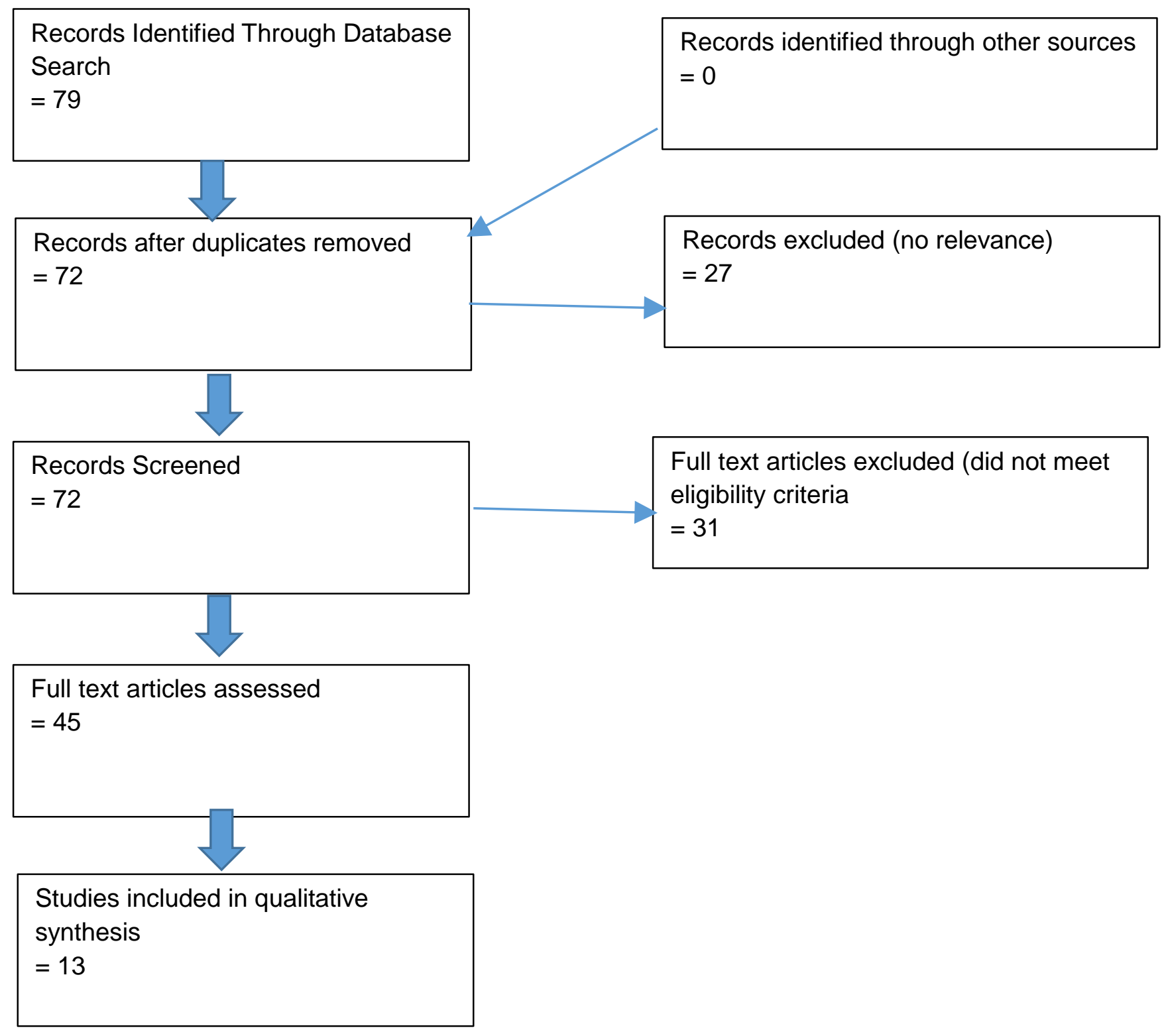

\section{RESULTS AND DISCUSSION}

Thematic analysis was used to determine, analyse and report themes (patterns) within the data (Braun \& Clarke, 2006). The data was explored and reviewed on multiple occasions and common themes were identified. The thematic analysis of the articles identified five main themes related to vicarious trauma in mental health staff. Table 1 below provides key methodological features

To be published in the Journal of Forensic Practice (in press) 
of the 13 included studies. The majority of the studies were conducted in the US and the UK.

Table 1: Methodological features of the 13 included articles

\begin{tabular}{|c|c|c|c|c|c|}
\hline Citation & Studies Aim & $\begin{array}{l}\text { Sample } \\
\text { Characteristics }\end{array}$ & $\begin{array}{l}\text { Data Collection } \\
\text { Method }\end{array}$ & $\begin{array}{l}\text { Method of } \\
\text { Analysis }\end{array}$ & $\begin{array}{l}\text { Trustworthiness } \\
\text { Ensured }\end{array}$ \\
\hline $\begin{array}{l}\text { Sprang et al. } \\
(2011)\end{array}$ & $\begin{array}{l}\text { To examine predictors } \\
\text { of secondary trauma } \\
\text { stress in child welfare } \\
\text { professionals and in } \\
\text { contrast to other } \\
\text { professional groups. }\end{array}$ & $\begin{array}{l}669 \text { child } \\
\text { welfare } \\
\text { professionals }\end{array}$ & $\begin{array}{l}\text { Online } \\
\text { Questionnaires }\end{array}$ & $\begin{array}{l}\text { T-Tests and } \\
\text { one-way } \\
\text { ANOVA } \\
\text { with post- } \\
\text { hoc tests; } \\
\text { regression } \\
\text { models }\end{array}$ & $\begin{array}{l}\text { (Not included in } \\
\text { article) }\end{array}$ \\
\hline $\begin{array}{l}\text { Creamer \& } \\
\text { Liddle (2005) }\end{array}$ & $\begin{array}{l}\text { To understand risk } \\
\text { factors that may then } \\
\text { allow organisations to } \\
\text { establish policies } \\
\text { designed to minimise } \\
\text { these risks. }\end{array}$ & $\begin{array}{l}80 \text { mental } \\
\text { health } \\
\text { professionals } \\
\text { who worked } \\
\text { with those } \\
\text { clients (adults } \\
\text { and children) } \\
\text { traumatised } \\
\text { by the } \\
\text { September } \\
11^{\text {th }}, 2001 \\
\text { terrorist attack } \\
\text { in the USA. }\end{array}$ & Questionnaires & $\begin{array}{l}\text { Multiple } \\
\text { Regressions }\end{array}$ & $\begin{array}{l}\text { (Not included in } \\
\text { article) }\end{array}$ \\
\hline $\begin{array}{l}\text { McElvaney \& } \\
\text { Tatlow-Golden } \\
\text { (2016) }\end{array}$ & $\begin{array}{l}\text { To explore } \\
\text { professionals' } \\
\text { experiences of } \\
\text { working with young } \\
\text { people in the care } \\
\text { and youth justice } \\
\text { context in Ireland, } \\
\text { focusing on the issue } \\
\text { of mental health } \\
\text { need. }\end{array}$ & $\begin{array}{l}26 \\
\text { professionals } \\
\text { working in } \\
\text { care and youth } \\
\text { justice services } \\
\text { in Ireland. } \\
\text { Purposeful } \\
\text { sampling was } \\
\text { used. }\end{array}$ & $\begin{array}{l}\text { Focus groups } \\
\text { and Interviews }\end{array}$ & $\begin{array}{l}\text { Thematic } \\
\text { Analysis }\end{array}$ & $\begin{array}{l}\text { Codes and } \\
\text { themes were } \\
\text { reviewed, } \\
\text { discussed and } \\
\text { agreed upon/ } \\
\text { Member } \\
\text { checking stage }\end{array}$ \\
\hline $\begin{array}{l}\text { VanDeusen \& } \\
\text { Way (2006) }\end{array}$ & $\begin{array}{l}\text { Investigating the } \\
\text { effects of providing } \\
\text { sexual abuse } \\
\text { treatment on } \\
\text { disruptions in } \\
\text { clinicians' thinking } \\
\text { about trust of, and } \\
\text { intimacy with others. }\end{array}$ & $\begin{array}{l}\text { Random } \\
\text { sample of } \\
\text { clinicians } \\
\text { (males and } \\
\text { female) who } \\
\text { treat sexual } \\
\text { abuse } \\
\text { survivors and }\end{array}$ & Questionnaires & $\begin{array}{l}\text { Sequential } \\
\text { Regression } \\
\text { Analysis }\end{array}$ & $\begin{array}{l}\text { (Not included in } \\
\text { article) }\end{array}$ \\
\hline
\end{tabular}

To be published in the Journal of Forensic Practice (in press) 


\begin{tabular}{|c|c|c|c|c|c|}
\hline & & $\begin{array}{l}\text { sexual } \\
\text { offenders }\end{array}$ & & & \\
\hline $\begin{array}{l}\text { Lonergan et al. } \\
\text { (2004) }\end{array}$ & $\begin{array}{l}\text { To explore how } \\
\text { trauma therapists } \\
\text { made meaning of } \\
\text { their experience in } \\
\text { working with } \\
\text { traumatised children } \\
\text { (trauma not } \\
\text { specified). Specifically } \\
\text { how they understood } \\
\text { their work, how the } \\
\text { work impacted them } \\
\text { and how they held on } \\
\text { to hope and persisted } \\
\text { in this field despite all } \\
\text { the challenges. }\end{array}$ & $\begin{array}{l}\text { Purposeful } \\
\text { sampling of } 8 \\
\text { therapists who } \\
\text { view } \\
\text { themselves as } \\
\text { specialists in } \\
\text { child trauma } \\
\text { work. }\end{array}$ & $\begin{array}{l}\text { Semi-structured } \\
\text { interviews }\end{array}$ & $\begin{array}{l}\text { Thematic } \\
\text { Analysis }\end{array}$ & $\begin{array}{l}\text { Second co- } \\
\text { author read } \\
\text { transcripts and } \\
\text { independently } \\
\text { developed initial } \\
\text { (first-level) } \\
\text { coding } \\
\text { schemes/ } \\
\text { Member } \\
\text { checking }\end{array}$ \\
\hline Osofsky (2011) & $\begin{array}{l}\text { To look at what } \\
\text { vicarious trauma and } \\
\text { compassion fatigue } \\
\text { are, how the effects } \\
\text { may be presented, } \\
\text { and the suggestions } \\
\text { for individual and } \\
\text { organisations for } \\
\text { prevention and } \\
\text { intervention } \\
\text { methods. }\end{array}$ & $\begin{array}{l}\text { Individuals } \\
\text { (including: } \\
\text { mental health } \\
\text { evaluators and } \\
\text { therapists, } \\
\text { judges, } \\
\text { lawyers, } \\
\text { children } \\
\text { welfare } \\
\text { professionals, } \\
\text { first } \\
\text { responders } \\
\text { and others) } \\
\text { who work with } \\
\text { traumatised } \\
\text { young children } \\
\text { and their } \\
\text { families }\end{array}$ & Questionnaires & $\begin{array}{l}\text { (Not } \\
\text { included in } \\
\text { article) }\end{array}$ & $\begin{array}{l}\text { (Not included in } \\
\text { article) }\end{array}$ \\
\hline $\begin{array}{l}\text { Way et al. } \\
(2004)\end{array}$ & $\begin{array}{l}\text { To understand the } \\
\text { level of VT in } \\
\text { therapists working } \\
\text { with survivors and } \\
\text { offenders, the } \\
\text { variables related with } \\
\text { VT, and if those } \\
\text { variables differ for } \\
\text { those working with }\end{array}$ & $\begin{array}{l}\text { Random } \\
\text { sample of } 347 \\
\text { clinicians who } \\
\text { treat survivors } \\
\text { of sexual } \\
\text { abuse (adults } \\
\text { who } \\
\text { experienced } \\
\text { childhood }\end{array}$ & Questionnaires & $\begin{array}{l}\text { Sequential } \\
\text { Regression } \\
\text { Analysis }\end{array}$ & $\begin{array}{l}\text { Anonymous } \\
\text { Survey }\end{array}$ \\
\hline
\end{tabular}

To be published in the Journal of Forensic Practice (in press) 


\begin{tabular}{|c|c|c|c|c|c|}
\hline & $\begin{array}{l}\text { different client } \\
\text { populations. }\end{array}$ & $\begin{array}{l}\text { sexual abuse } \\
\text { and those who } \\
\text { experienced } \\
\text { abuse as } \\
\text { adults) and } \\
\text { sexual } \\
\text { offenders }\end{array}$ & & & \\
\hline $\begin{array}{l}\text { Neumann \& } \\
\text { Gamble (1995) }\end{array}$ & $\begin{array}{l}\text { To look at } \\
\text { countertransference } \\
\text { responses, the } \\
\text { phenomenon of } \\
\text { vicarious trauma, and } \\
\text { the personal and } \\
\text { organisational factors } \\
\text { that can ameliorate } \\
\text { the negative } \\
\text { symptoms of trauma } \\
\text { work. }\end{array}$ & $\begin{array}{l}\text { Psychotherapi } \\
\text { sts (especially } \\
\text { those new to } \\
\text { the field of } \\
\text { traumatology) } \\
\text { working with } \\
\text { survivors of } \\
\text { chronic } \\
\text { childhood } \\
\text { trauma. }\end{array}$ & $\begin{array}{l}\text { (Not included in } \\
\text { article) }\end{array}$ & $\begin{array}{l}\text { (Not } \\
\text { included in } \\
\text { article) }\end{array}$ & $\begin{array}{l}\text { (Not included in } \\
\text { article) }\end{array}$ \\
\hline $\begin{array}{l}\text { Brady et al. } \\
\text { (1999) }\end{array}$ & $\begin{array}{l}\text { To examine the VT of } \\
\text { women } \\
\text { psychotherapists } \\
\text { attributable to their } \\
\text { work with sexual } \\
\text { abuse survivors. }\end{array}$ & $\begin{array}{l}\text { Randomized } \\
\text { sample of } 446 \\
\text { women } \\
\text { psychotherapi } \\
\text { sts }\end{array}$ & Questionnaires & $\begin{array}{l}\text { One-way } \\
\text { ANVOAs }\end{array}$ & $\begin{array}{l}\text { (Not included in } \\
\text { article) }\end{array}$ \\
\hline Motta (2012) & $\begin{array}{l}\text { Assessment devices } \\
\text { for secondary trauma } \\
\text { were reviewed and } \\
\text { evaluated the efficacy } \\
\text { of therapeutic } \\
\text { interventions for } \\
\text { secondary } \\
\text { traumatisation found } \\
\text { in children, school } \\
\text { mental health } \\
\text { workers and teachers. }\end{array}$ & $\begin{array}{l}\text { Case study of } \\
\text { child who } \\
\text { experienced } \\
\text { secondary } \\
\text { trauma from } \\
\text { father's } \\
\text { experience; } \\
\text { mental health } \\
\text { professionals } \\
\text { working in } \\
\text { schools and } \\
\text { teachers who } \\
\text { experience } \\
\text { secondary } \\
\text { trauma from } \\
\text { students. }\end{array}$ & $\begin{array}{l}\text { Literature } \\
\text { Review }\end{array}$ & $\begin{array}{l}\text { (Not } \\
\text { included in } \\
\text { article) }\end{array}$ & $\begin{array}{l}\text { (Not included in } \\
\text { article) }\end{array}$ \\
\hline Pistorius (2006) & $\begin{array}{l}\text { To understand } \\
\text { therapists' personal } \\
\text { experiences and how } \\
\text { working with sexually }\end{array}$ & $\begin{array}{l}14 \text { female } \\
\text { licensed } \\
\text { therapists } \\
\text { working with }\end{array}$ & $\begin{array}{l}\text { Unstructured } \\
\text { Interviews }\end{array}$ & $\begin{array}{l}\text { Thematic } \\
\text { Analysis }\end{array}$ & $\begin{array}{l}\text { Transcription of } \\
\text { interviews } \\
\text { checked; all four } \\
\text { analysts assisted }\end{array}$ \\
\hline
\end{tabular}

To be published in the Journal of Forensic Practice (in press) 


\begin{tabular}{|c|c|c|c|c|c|}
\hline & $\begin{array}{l}\text { abused children } \\
\text { impacts their } \\
\text { personal lives. }\end{array}$ & $\begin{array}{l}\text { sexually- } \\
\text { abused } \\
\text { children }\end{array}$ & & & $\begin{array}{l}\text { in coding and } \\
\text { used constant- } \\
\text { comparative } \\
\text { method to } \\
\text { extract themes }\end{array}$ \\
\hline Braley (2010) & $\begin{array}{l}\text { To determine the } \\
\text { relationship between } \\
\text { exposure to traumatic } \\
\text { experiences of } \\
\text { hospitalised children } \\
\text { and adolescents and } \\
\text { the development of } \\
\text { secondary traumatic } \\
\text { stress in clinical staff } \\
\text { working with such } \\
\text { patients. }\end{array}$ & $\begin{array}{l}268 \text { faculty } \\
\text { and staff in } \\
\text { surgery, } \\
\text { medicine, } \\
\text { nursing, social } \\
\text { work, } \\
\text { psychiatry, } \\
\text { psychology, } \\
\text { allied health, } \\
\text { and child and } \\
\text { family services } \\
\text { were recruited } \\
\text { to participate. }\end{array}$ & Questionnaires & $\begin{array}{l}\text { Hierarchical } \\
\text { regression }\end{array}$ & $\begin{array}{l}\text { (Not included in } \\
\text { article) }\end{array}$ \\
\hline Weaks (1999) & $\begin{array}{l}\text { To examine vicarious } \\
\text { trauma and coping in } \\
\text { psychotherapists. }\end{array}$ & $\begin{array}{l}95 \text { licensed } \\
\text { professional } \\
\text { counsellors } \\
\text { and licensed } \\
\text { psychologists } \\
\text { (male and } \\
\text { female). Over } \\
\text { their careers, } \\
\text { they estimated } \\
41 \% \text { of their } \\
\text { clients were } \\
\text { trauma } \\
\text { survivors } \\
\text { (trauma not } \\
\text { specified). }\end{array}$ & Questionnaires & $\begin{array}{l}\text { MANOVA } \\
\text { and ANOVA }\end{array}$ & $\begin{array}{l}\text { (Not included in } \\
\text { article) }\end{array}$ \\
\hline
\end{tabular}

From considering the above themes, and after ensuring reliability with another researcher who had not been part of the project, the following themes from the data were noted, and which were linked to vicarious and secondary trauma in staff. These are as follows:

\section{THEME 1: Lack of organisational support}

This is referring to support from colleagues, peers, supervisors and the organisation (Choi, 2011). Without adequate support and debriefing, staff can feel overwhelmed with the work and To be published in the Journal of Forensic Practice (in press) 
experience more stress (Lonergan et al., 2004; Pistorius, 2006; VanDeusen \& Way, 2006). Those experiencing vicarious trauma hinder their colleagues by not being available for consultation or supervision, or by lowering moral by displaying cynicism (Weaks, 1999). This cynicism can lead to retraumatising clients by focusing on their own needs, over the needs of the clients, disrupting boundaries. These boundaries can include forgotten appointments, client abandonment, abuse of the client, or professional mistreatment (Weaks, 1999), which has a negative impact on the professionalism of the organisation. Organisations can then face burnout and shortened careers of their staff, leading to high staff turnover and the need for finding and training replacements (Weaks, 1999). Additionally, ineffective inter-agency communication can increase stress on therapists (McElvaney \& Tatlow-Golden, 2016). Finding effective ways of sharing information and reducing misunderstandings may help reduce stress (McElvaney \& Tatlow-Golden, 2016).

\section{THEME 2: Lack of healthy work-life balance}

Being unable to have clear boundaries between work hours and off-work hours was identified to be a source of frustration to mental health workers. Being assigned too many cases, handling too many traumatic cases, working over-time, not taking vacations or holidays all may contribute to the development of vicarious trauma (Pistorius, 2006). Having a fulfilling personal life and engaging in healthy intimate relationships can aid in safe-guarding the professional's mental health and provide support against vicarious trauma (Neumann \& Gamble, 1995; Osofsky, 2011). Being involved in activities or hobbies (such as creating art or engaging in religious activities) can restore a sense of meaning, connection with others, and hope, which can lead to lower levels of burnout (Neumann \& Gamble, 1995).

\section{THEME 3: Lack of appropriate training}

While many mental health staff had heard about vicarious trauma in their work, there was a distinct lack of training on protective measures or information on what to do if they begin to experience the effects of vicarious trauma (Brady et al., 1999; Osofsky, 2011). Staff with higher levels of education and external support for stress where found to have lower compassion fatigue scores (Braley, 2010). Newer therapists, as an example, who generally have less education and training, are more likely to experience symptoms of trauma (Neumann \& Gamble, 1995). Trauma-

To be published in the Journal of Forensic Practice (in press) 
specific training would be helpful for staff, as it would increase their competency in trauma treatment and provide better care for the client. This is vital since knowledge in this field is advancing quickly (Weaks, 1999).

\section{THEME 4: Failure to use self-care techniques}

Many of the staff identified the importance of self-care techniques for others and how beneficial they are, but many failed to specifically implement these techniques into their life (Motta, 2012; Neumann \& Gamble, 1995; Lonergan et al., 2004; Osofsky, 2011). Self-care techniques can include regular exercise, eating a healthy diet, taking vacations and breaks from work, diversifying their caseloads, and limiting the amount of particularly difficult cases, could help prevent or reduce the compassion fatigue experienced by staff. Some staff reported using negative coping strategies, such as drinking alcohol to cope, and which is of concern.

\section{THEME 5: Staff failure to share when they are experiencing symptoms}

Staff often failed to report when they were feeling overwhelmed with specific cases, or with the workload because they believed that if they were experiencing negative effects from the job, this would mean that they aren't doing their job properly or they are not suited for this field. Since they don't share when they are beginning to experience symptoms, measures cannot be put into place to reduce the effects (Choi, 2011; McElvaney \& Tatlow-Golden, 2016). Therapists reported that having supervision and dedicated times to discuss their experiences helped them (Lonergan et al., 2004; Pistorius, 2006; VanDeusen \& Way, 2006). Learning how to unofficially debrief with colleagues allowed staff to de-stress. Regular debriefing with colleagues or supervisors, or attending personal therapy, may help to de-stress and allow others to identify vicarious trauma symptoms they may not have noticed in themselves (VanDeusen \& Way, 2006). If the individual, or colleagues, notice symptoms, then measures can be put in place to reduce the levels of stress and avoid burnout.

The five mains themes highlighted that there are ways to reduce or avoid vicarious and secondary trauma in staff. As previously noted, the symptoms can be detrimental to staff, the organisation and the client, if left untreated. Therefore, it is essential that policies, supported by literature, are developed to mitigate these effects. Education of organisations and individual staff To be published in the Journal of Forensic Practice (in press) 
members is critical, as it allows staff to understand and recognise when they may be experiencing symptoms (Braley et al., 1999; Osofsky, 2011). The education should focus on various aspects, such as how to recognise symptoms, appropriate self-care techniques, as well as what the organisation offers in terms of support. Employees that are aware of the symptoms may feel less shame and embarrassment, as they realise it is common to experience vicarious and secondary trauma. With less negativity surrounding their symptoms this can help staff feel more comfortable seeking support from colleagues. Further, offering employees' time for discussing their experiences can reduce overall stress and reduce the likelihood of them experiencing vicarious trauma symptoms (Braley, 2010).

Organisations should be mindful to review any systemic issues regularly, and to support help where there are weaknesses (Brady et al., 1999). Ensuring that there is communication within all agencies of the organisation and between management, can decrease the stress felt by staff (Choi, 2011; McElvaney \& Tatlow-Golden, 2016). Newer staff members should be monitored closely, as they are more likely to experience symptoms of vicarious trauma (Neumann \& Gamble, 1995). Having a healthy work-life balance was significantly linked with decrease symptoms of various trauma (Pistorius, 2006). Organisations can ensure staff are not working too many hours or have too many trauma clients in their case-load, in order to reduce stress felt by staff (Pistorius, 2006).

\section{Limitations}

Due to limited research in this area, the search terms had to be widened to include a broader range of professionals who work with children experiencing psychological trauma. As such, these results may potentially not be fully generalisable. There may also be a self-selection bias, where individuals may be either more likely or less likely to volunteer as a participant in the research topic. For instance, and as one of the themes indicated, staff may feel stigmatised if they are experiencing negative symptoms and may not want to participate in these studies. The articles that were analysed did not take into account staff that may have already changed jobs or field of work due to vicarious and secondary trauma. Further, some of the articles relied on selfreport and there may be a response bias, to appear in a more positive way.

To be published in the Journal of Forensic Practice (in press) 
Implications for Research

There is a limited amount of research undertaken on vicarious and secondary trauma, particularly in those who specifically work with children. The initial search only identified three articles that met the initial criteria, and where it then had to be broadened. Further research is needed specifically with residential workers who work with traumatised children, since they are more involved in the day-to-day care and arguably more exposed to effects of these youths' traumas. This should also apply to foster carers. It should further aim to separate any traumatic responses from staff who have been exposed to direct trauma in the workplace, such as those from clients, versus those that have been exposed to potential trauma through the viewing of distressing material only. Many of the studies found conflicting information regarding factors leading to vicarious and secondary trauma, so there is a need for further exploration and clarification. While the articles in this systematic review highlighted the importance of a staff's coping strategies, there is still a need for research that examines the effectiveness of these coping strategies, as well as what reduces symptomatology.

Implications for staff and policy-makers

This area of research can aid with the development or refinement of specific policies for staff, in order to create an environment that is more likely to reduce or mitigate the effects of vicarious and secondary trauma. The effects are widespread and affect the staff member, the client and the organisation as a whole. Both the staff member and the organisation where they work have the responsibility to take the necessary steps to reduce the likelihood of developing vicarious and secondary trauma, or reducing already presenting symptomatology. This research can provide staff with information that can assist them in understanding some of the risks that come with the job and provide suggestions of self-care. Organisations can further ensure there is sufficient and effective supervision of their employees. Specific training that addresses the issue of vicarious and secondary trauma can potentially provide an environment where employees feel more comfortable discussing such trauma. As part of this, organisations can consider the case load of staff, to ensure they are not overwhelmed, or that their employee's

To be published in the Journal of Forensic Practice (in press) 
caseloads are more diversified between traumatised and non-traumatised clients.

\section{CONCLUSION}

This review provides an exploration of articles regarding vicarious and secondary trauma in staff who work with children. Due to the severe symptoms individuals can present with, it is important that there is a deeper understanding of such trauma. This systematic review identified 5 main themes which can contribute to the development of symptoms: lack of organisational support; lack of health work-life balance; lack of appropriate training; failure to use self-care techniques; and staff failure to share when they are experiencing symptoms. The results of this review can be used to guide further research and provide staff and organisations with information in order to create guidelines.

\section{Implications for practice}

- It is important for the topic of secondary and vicarious trauma to be noted in staff teams, with a clear avenue of support in place. This should further include the use of supportive policies that have an empirical basis. Education and support is crucial as part of this.

- Organisations and staff should be aware that newer staff may be considered an 'at risk' group for the negative impact of such trauma, but not to disregard the more established staff groups.

- Staff should be encouraged in achieving an effective work-life balance, and organisations should be instrumental in this.

- Organisations should ensure mechanisms and procedures are in place to prevent the risk of such trauma, and to minimise the impact if and when it presents in staff teams.

\section{REFERENCES}

American Psychological Association. (2014). Diagnostic and Statistical Manual of Mental Disorders. Washington DC: APA.

Bishop, S., \& Schmidt, G. (2011). Vicarious Traumatization and Transition House Workers in To be published in the Journal of Forensic Practice (in press) 
Remote, Northern British Columbia Communities. Rural Society, 21(1), 65-73.

Brady, J.H., Guy, J.D., Poelstra, P.L. \& Brokaw, B.F. (1999). Vicarious Traumatization, Spirituality, and the Treatment of Sexual Abuse Survivors: A National Survey of Women Psychotherapists. Professional Psychology, Research and Practice, Vol 30 (4), 386-393

Braley, R.A. (2010). Effects of Patient Trauma on Hospital Staff Functioning: An Exploratory Study of Psychological Distress Resulting From Trauma Exposure, Electronic Theses and Dissertations, Paper 767.

Braun, V., \& Clarke, V. (2006). Using thematic analysis in psychology. Qualitative Research in Psychology, 3, 77-101.

Choi, G. Y. (2011). Organizational Impacts on the Secondary Traumatic Stress of Social Workers Assisting Family Violence or Sexual Assault Survivors. Administration in Social Work, 35(3), 225-242.

Creamer, T. L. \& Liddle, B.J. (2005). Secondary Traumatic Stress among Disaster Mental Health Workers Responding to the September 11 Attacks. Journal of Traumatic Stress, 18, 89-96. Kindy, D., Peterson, S. \& Parkhurst, D. (2005). Perilous Work: Nurses' Experiences in Psychiatric Units with High Risks of Assault. Archives of Psychiatric Nursing, 19 (4), 169-175.

Lonergan, B.A., O'Halloran, M.S., \& Crane, S.C.M. (2004). The Development of the Trauma Therapists: A Qualitative Study of the Child Therapist's Perspectives and Experiences. Brief Treatment and Crisis Intervention, 4, 353-366.

McElvaney, R. \& Tatlow-Golden, M. (2016). A Traumatised and Traumatising system: Professionals' Experience in Meeting the Mental Health Needs of Young people in the Care and Youth Justice Systems in Ireland, Children and Youth Services Review, 65, 62-69.

McCann, I. L., \& Pearlman, L. A. (1990). Vicarious traumatization: A framework the psychological effects of working with victims. Journal of Traumatic Stress, 3(1), 131-149.

Motta, R.W. (2012). Secondary Trauma in Children and School Personnel. Journal of Applied School Psychology, 28 (3), 256-269.

Neuman, D.A. \& Gamble, S.J. (1995). Issues in the Professional Development of Psychotherapists: Countertransference and vicarious Traumatization in the new Trauma Therapist. Psychotherapy, 32, 2.

To be published in the Journal of Forensic Practice (in press) 
Osofsky, J.D. (2011). Vicarious Traumatization and the Need for Self-Care in Working with Traumatized Young Children (page 336 - 348). In: Clinical Work with Traumatized Young Children, Guildford Press: New York. Retrieved 19.10.17: http://www.louisianachildren.org/media/12000/Vicarious-Traumatization.pdf

Pistorius, K.D. (2006). The Personal Impact on Female Therapists from Working with SexuallyAbused Children. All Theses and Dissertations. Paper 394. Retrieved 19.10.17: http://scholarsarchive.byu.edu/cgi/viewcontent.cgi?article=1393\&context=etd

Skogstad, M., Skorstad, M., Lie, A., Conradi, H.S., Heir, T. \& Weisaeth, L. (2003). Work-related post-traumatic stress disorder. Occupational Medicine, 63 (3), 175-182.

Sprang, G., Craig, C. \& Clark, J. (2011). Secondary Traumatic Stress and Burnout in Child Welfare Workers: A Comparative Analysis of Occupational Distress across Professional Groups. Child Welfare, 90, 6-149.

Thomas, J. \& Harden, A. (2008). Methods for the thematic synthesis of qualitative research in systematic reviews. BMC Medical Research Methodology, 8, 45.

VanDeusen, K.M. \& Way, I. (2005). Vicarious Trauma: An Exploratory Study of the Impact of Providing Sexual Abuse Treatment on Clinicians' Trust and Intimacy. Journal of Child Sexual Abuse, Vol 15 (1), $69-85$.

Wagaman, M. A., Geiger, J. M., Shockley, C., \& Segal, E. A. (2015). The Role of Empathy in Burnout, Compassion Satisfaction, and Secondary Traumatic Stress among Social Workers. Social work, 60(3), 201-209.

Way, I., VanDeusen, K.M., Martin, G., Applegate, B., \& Jandle, D. (2016). Vicarious Trauma: A Comparison of Clinicians Who Treat Survivors of Sexual Abuse and Sexual Offenders. Journal of Interpersonal Violence; 19, (1), 49-71.

Weaks, K.A. (1999). Effects of treating Trauma Survivors: Vicarious Traumatization and Style of Coping. Texas Woman's University. Unpublished PhD Thesis. Retrieved 19.10.17: https://www.researchgate.net/publication/33806681 Effects of treating trauma surviv ors Vicarious traumatization and style of coping

To be published in the Journal of Forensic Practice (in press) 